\title{
St. Jude Medical prosthesis in children
}

From December 1980 through April 1992, 20 children 2 to 18 years of age underwent valve replacement with the St. Jude Medical prosthesis. Nine children underwent aortic valve replacement, eight underwent mitral valve replacement, and the three children with corrected transposition underwent left-sided tricuspid valve replacement. Of the 20 patients, 17 underwent 23 previous procedures. All but five patients received adequate adult-sized prostheses. There was one hospital death (5\%). All hospital survivors received maintenance doses of sodium warfarin. Follow-up was $100 \%$ complete with a total of 106 patient-years. There were no late deaths and no thromboembolic or anticoagulant-related bleeding. None of the patients had prosthetic valve endocarditis or a periprosthetic leak. Reoperation was not required in any patient. The great majority of the children (16 of 19) were in New York Heart Association functional class I, two were in class II, and one with complex congenital heart disease was in class III at the time this article was written. This study illustrates the excellent results of cardiac valve replacement with the St. Jude Medical prosthesis in children and confirms the safety of sodium warfarin in this age group. (J THORAC CARDIOvaSC SuRG 1994;108;52-6)

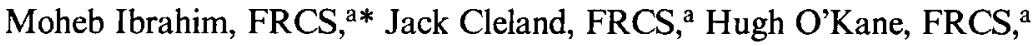

Dennis Gladstone, FRCS, ${ }^{a}$ Conor Mullholland, FRCP, ${ }^{\mathrm{b}}$ and Brian Craig, MRCP,

Belfast, Northern Ireland

\begin{abstract}
A ccelerated calcification and valvular dysfunction of bioprostheses in children ${ }^{1-7}$ have made the use of mechanical prostheses for this particular age group more acceptable to cardiac surgeons. However, the problem of somatic growth, ${ }^{8,9}$ resulting in patient/valve mismatch, remains a matter of concern. In addition, the decision to maintain children anticoagulation therapy in children and the type of anticoagulant used after mechanical valve replacement remain controversial. ${ }^{10-18} \mathrm{We}$ present our experience with the St. Jude Medical prosthesis (St. Jude Medical, Inc., St. Paul, Minn.) in children.

\section{Patients and methods}

From December 1980 through April 1992, 20 children, ranging from 2 to 18 years of age (mean 10.3 years), underwent

From the Departments of Cardiac Surgery and Pediatric Cardiology, Royal Victoria Hospital, Belfast, Northern Ireland.

Received for publication Aug. 24, 1993.

Accepted for publication Dec. 12, 1993.

Address for reprints: Jack Cleland, FRCS, Department of Cardiac Surgery, Royal Victoria Hospital, Belfast, BT12 6BA, Northern Ireland.

*Present address: Division of Cardiothoracic Surgery, University of Ottawa Heart Institute, Ottawa Civic Hospital, 1053 Carling Ave., Ottawa, Ontario, Canada KIY 4E9.

Copyright $\odot 1994$ by Mosby-Year Book, Inc.

$0022-5223 / 94 \$ 3.00+0 \quad 12 / 1 / 54086$
\end{abstract}

cardiac valve replacement with the St. Jude Medical prosthesis at the Royal Victoria Hospital. Fig. 1 shows age distribution of the study population: 11 boys and 9 girls. Eleven (55\%) children were in New York Heart Association (NYHA) class III or IV before the operation.

Nine children underwent aortic valve replacement (AVR), eight underwent mitral valve replacement (MVR), and three patients who had congenitally corrected transposition of the great arteries underwent replacement of the morphologically tricuspid left atrioventricular valve. Table I shows the original lesions of the valves replaced with the St. Jude Medical prosthesis.

Seventeen patients underwent 23 previous operations as shown in Table II. Five patients in the MVR group underwent eight previous operations on the mitral valve. Among these patients, one had two previous mitral valve replacements with a bioprosthesis. One patient who had a parachute mitral valve required MVR after two unsuccessful valvotomies. Six patients had valve replacement at their initial operation. Three had corrected transposition of the great vessels. Repair was attempted but was unsuccessful. In the remaining three cases, one attempted repair was unsuccessful, another in a patient with acute rheumatic fever was thought to involve bacterial endocarditis, and the case involving traumatic mitral regurgitation was also not repairable. Of the nine patients in the AVR group, six required eight previous operations on the aortic valve. In the other three patients (Marfan's syndrome, myxomatous degeneration, and acute bacterial endocarditis) replacement was mandatory.

Cardiopulmonary bypass and systemic hypothermia were used for all procedures. Myocardial protection was provided with cold crystalloid or blood cardioplegic solution and topical 


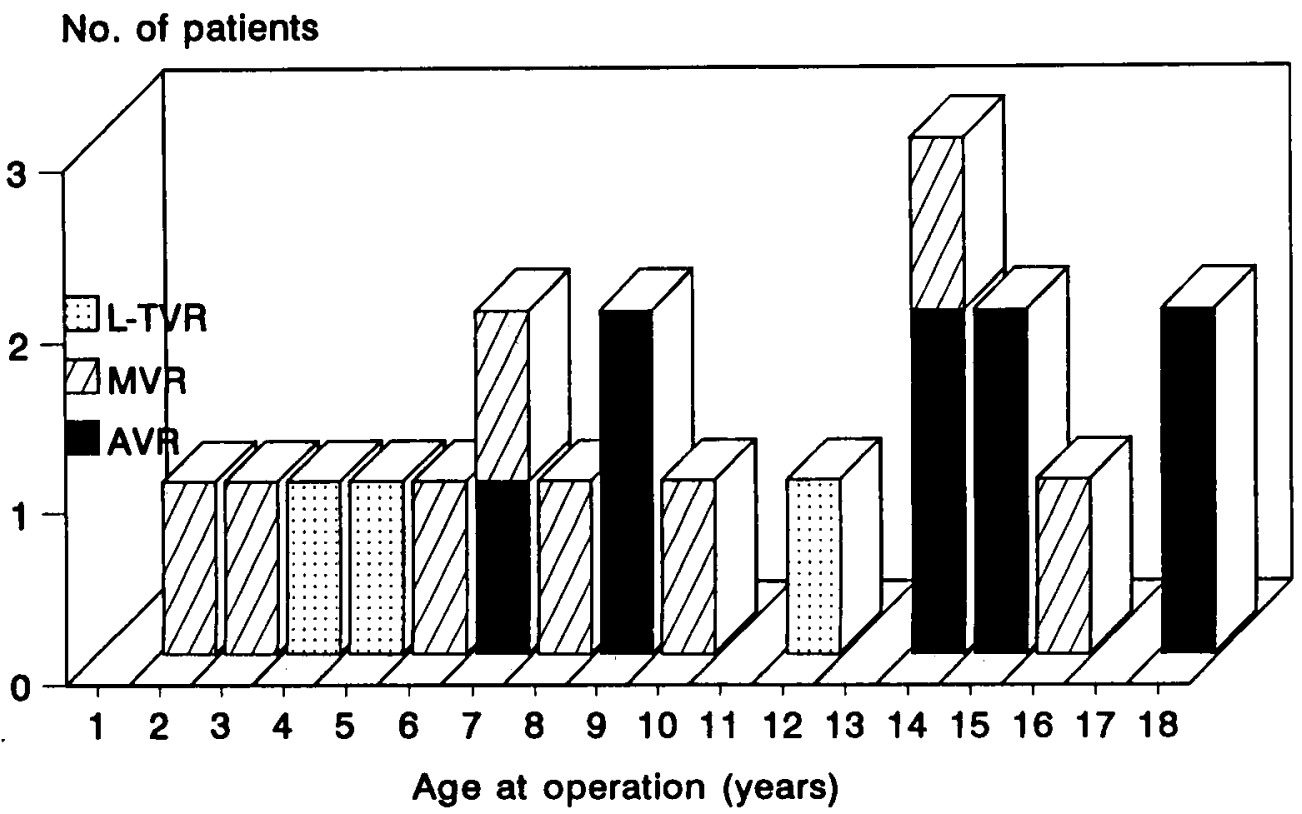

Fig. 1. Age at valve replacement with the St. Jude Medical prosthesis. $L-T V R$, Left-sided tricuspid valve replacement.

hypothermia. All valves were implanted by means of a continuous suture technique. Four patients required additional procedures (Table III). Three of the four patients were in the AVR group. The size of the St. Jude Medical prostheses used is shown in Table IV. All but five patients received adequate adult-sized prostheses. One patient 2 years of age who required two previous valvotomies for congenital mitral stenosis, received a $19 \mathrm{~mm}$ aortic prosthesis; another patient required enlargement of the aortic root with a pericardial patch to allow insertion of a $19 \mathrm{~mm}$ valve. A $29 \mathrm{~mm}$ prosthesis was inserted in the aortic position in two patients. One of these two patients had Marfan's syndrome, and the other had dilated aortic root without aneurysm formation.

Sodium warfarin therapy was started on the second postoperative day for all patients. The warfarin dose was modified to keep the prothrombin time measured as International Normalized Ratio (INR) between 2.0 to 2.5 (prothrombin time ratio of 1.7 to 1.9). The actuarial method was used to summarize overall mortality. Survival estimates are recorded \pm the standard error of the estimate (Fig. 2).

\section{Results}

There was only one hospital death (5\%). This patient was 9 years of age and was known to have bicuspid aortic valve and coarctation of the aorta. She had Staphylococcus aureus endocarditis and underwent AVR and exclusion of a mycotic aneurysm of the aorta with the use of a pericardial patch. After the operation, she had a septic renal infarct and, at reoperation, through a thoracotomy, a large mycotic aneurysm of the descending aorta distal to the coarctation was found. Resection of the coarctation
Table I. Original lesions of valves replaced with St. Jude Medical prostheses

\begin{tabular}{lc}
\multicolumn{1}{c}{ Lesion } & $\begin{array}{c}\text { No. of } \\
\text { patients }\end{array}$ \\
\hline MVR & \\
Parachute mitral valve & 1 \\
Dysplastic mitral valve & 2 \\
MR with AV canal defect & 2 \\
Congenital MR (cleft leaflets) & 1 \\
Acute rheumatic fever & 1 \\
Traumatic MR & 1 \\
L-TVR & \\
Ebstein's anomaly of left-sided TV & 2 \\
TR (thickened and retracted leaflets) & 1 \\
AVR & \\
Bicuspid aortic valve & 5 \\
AR associated with VSD & 1 \\
AR caused by BE & 1 \\
Marfan's syndrome & 1 \\
Myxomatous degeneration & 1 \\
Total & 20 \\
\hline
\end{tabular}

$M R$, Mitral regurgitation: $A V$, atrioventricular: $L-T V R$, left-sided tricuspid valve replacement; $T V$, tricuspid valve; $T R$, tricuspid regurgitation; $A R$, aortic regurgitation; $V S D$, ventricular septal defect; $B E$, bacterial endocarditis.

together with the mycotic aneurysm and end-to-end anastomosis was performed; however, the patient's septicemia did not subside, and she died 2 months after the first operation. 
Table II. Previous procedures

\begin{tabular}{|c|c|c|}
\hline Procedure & $\begin{array}{c}\text { No. of } \\
\text { patients }\end{array}$ & $\begin{array}{c}\text { No. of previous } \\
\text { operations }\end{array}$ \\
\hline \multicolumn{3}{|l|}{ MVR group } \\
\hline Coarctation repair, mitral valvotomy & 1 & $3(1+2)$ \\
\hline Repair of A-V canal defect & 2 & 3 \\
\hline Repair of cleft mitral leaflets & 1 & 1 \\
\hline Previous MVR & 1 & 2 \\
\hline \multicolumn{3}{|l|}{ L-TVR group } \\
\hline Pulmonary valvotomy & 1 & 1 \\
\hline Pulmonary valvotomy and VSD repair & 1 & 1 \\
\hline Coarctation repair & 1 & 1 \\
\hline \multicolumn{3}{|l|}{ AVR group } \\
\hline Aortic valvotomy & 3 & 3 \\
\hline $\begin{array}{l}\text { Aortic and pulmonary valvotomy, then aortic valve repair and } \\
\text { myotomy }\end{array}$ & 1 & 2 \\
\hline Patch enlargement of pulmonary OT & 1 & 1 \\
\hline Aortic valve repair & 1 & 1 \\
\hline Repair of aortic valve and VSD & 1 & 2 \\
\hline Ligation of patent ductus arteriosus & 2 & 2 \\
\hline Total & 17 & 23 \\
\hline
\end{tabular}

$A-V$, Atrioventricular; $L-T V R$, left-sided tricuspid valve replacement; $V S D$, ventricular septal defect; $O T$, outflow tract.

Table III. Additional procedures

\begin{tabular}{lc}
\hline \multicolumn{1}{c}{ Procedure } & No. of \\
patients
\end{tabular}

The mean follow-up period was $5.3 \pm 0.78$ years, ranging from 0.47 to 11.77 years. The total follow-up was 106 patients-years. No patients were lost to follow-up. There was no late mortality or any thromboembolic or anticoagulant-related bleeding necessitating medical attention. The mean of the last five INR results for the whole group of patients was $2.3 \pm 0.07$ (range 1.90 to 2.98). Actuarial survival at 6 years was $95 \% \pm 5 \%$ (Fig. 2). No patient had prosthetic valve endocarditis (PVE) or required reoperation. The majority of patients (16 of 19) were in NYHA functional class I, and two patients were in class II. Only one patient was in class III. This patient had left-sided tricuspid valve replacement and had subvalvar pulmonary stenosis. Fifteen of the 19 survivors were in sinus rhythm, whereas only one patient was in atrial fibrillation at the time this article was written. Three patients required insertion of a permanent pacemaker that was not related to valve replacement (two before the operation and one late after the operation). Of these three patients, two had Ebstein's anomaly of the left-sided tri-
Table IV. Size of the St. Jude Medical prostheses used and age at operation

\begin{tabular}{ccc}
\hline $\begin{array}{c}\text { Prosthesis } \\
\text { size }(\mathrm{mm})\end{array}$ & $\begin{array}{c}\text { No. of } \\
\text { patients }\end{array}$ & $\begin{array}{c}\text { Age at operation } \\
(y r)\end{array}$ \\
\hline AVR & & 7,9 \\
19 & 2 & 9 \\
21 & 1 & 14,18 \\
23 & 2 & 15 \\
25 & 1 & 15 \\
27 & 1 & 14,18 \\
29 & 2 & \\
MVR & & 2 \\
19 & 1 & 6 \\
25 & 1 & 7 \\
27 & 1 & $3,8,10,16$ \\
29 & 4 & 14 \\
31 & 1 & \\
L-TVR & & 4 \\
23 & 1 & 5 \\
27 & 1 & 12 \\
31 & 1 &
\end{tabular}

$L-T V R$, Left-sided tricuspid valve replacement.

cuspid valve, and the third patient had a complete atrioventricular canal defect with two previous attempts at repair.

\section{Discussion}

Having exhausted all the efforts to repair cardiac valves in children, we find the use of the St. Jude Medical prosthesis as a valve substitute, with its low-profile structure, 


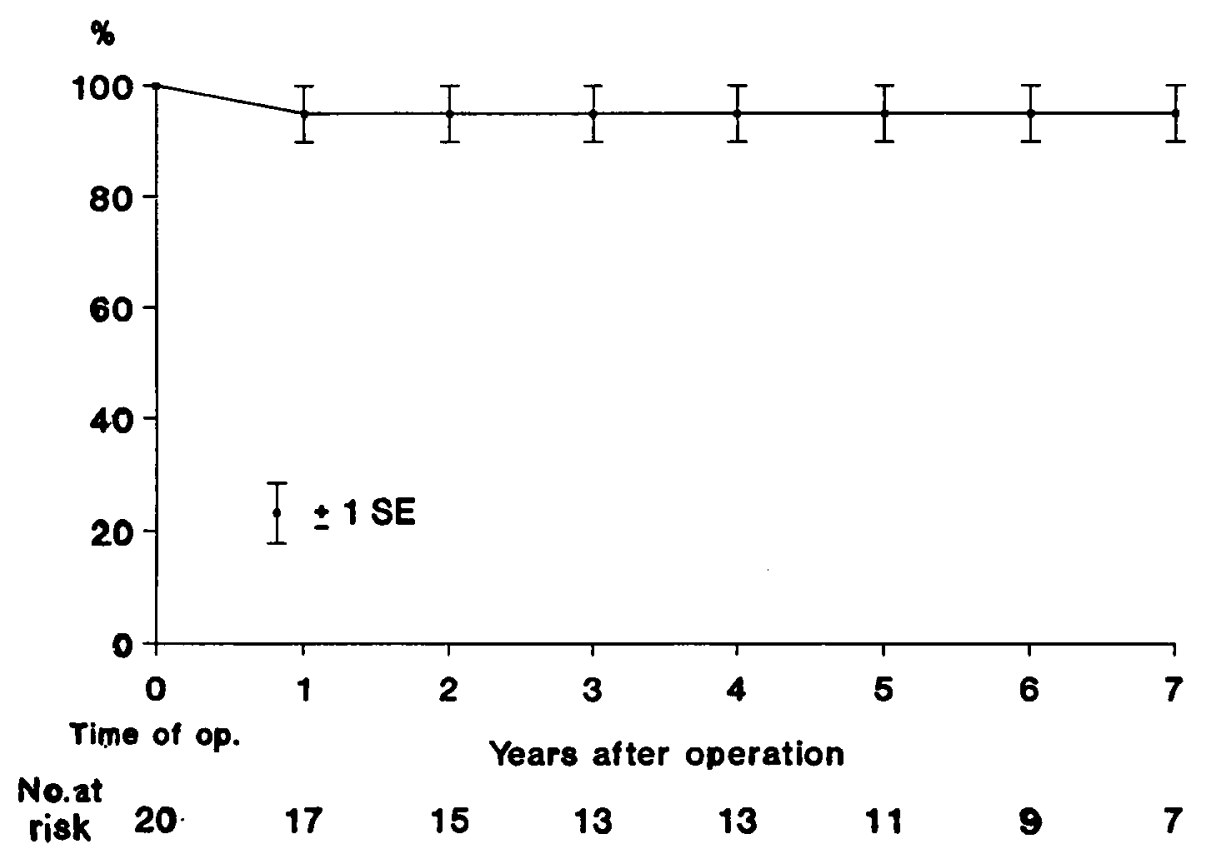

Fig. 2. Actuarial survival in children after valve replacement with the St. Jude Medical prosthesis.

appealing. Homograft replacement of the aortic valve is an attractive option but was not available for our patients. Our 5\% early mortality and $0 \%$ late mortality rates compare well with those of other series, including a variety of mechanical and tissue prostheses. ${ }^{10-24}$ However, none of the patients in our series was under 2 years of age.

Controversy continues regarding the decision to maintain anticoagulation therapy in active energetic children and the choice of the ideal anticoagulant for this particular age group. ${ }^{10-18}$ In our series, all patients were maintained on warfarin, and the INR was kept between 2 and 2.5. None of the patients had either a thromboembolic event or an anticoagulant-related hemorrhage. We believe that anticoagulation therapy with warfarin is essential for all children and that a therapeutic range of 2.0 to 2.5 can be achieved without difficulty. In the series of Sade and associates, ${ }^{12}$ the authors admitted that children who did not receive anticoagulants were significantly less free of thrombotic and thromboembolic events than were the adults who did receive anticoagulants. Some authors ${ }^{10,14,15}$ reported good results with antiplatelet drugs (aspirin and dipyridamole), whereas McGrath and associates ${ }^{16}$ concluded that full-dose warfarin therapy is superior to antiplatelet drugs. Rao and associates ${ }^{17}$ recommended that aspirin and dipyridamole are adequate for mechanical aortic valves, that warfarin may be needed in patients with a mitral valve prosthesis, but that warfarin anticoagulation should be prescribed for patients with double valve replacement. Borkon and associ- ates ${ }^{13}$ suggested that because of difficulties with achieving anticoagulation with warfarin, aspirin should be used for patients younger than 5 years of age, whereas older patients can be treated with warfarin.

None of the patients in our series required reoperation. Every effort was made to insert the largest possible prosthesis to avoid the problem of having to replace it in adult life. In the MVR group, the anulus was dilated enough to accept a prosthesis larger than $25 \mathrm{~mm}$ in diameter in all patients except two. One of these two patients received a $25 \mathrm{~mm}$ prosthesis. The second, who underwent two previous valvotomies for congenital mitral stenosis, had an anulus diameter of only $17 \mathrm{~mm}$. A $19 \mathrm{~mm}$ prosthesis was implanted and offset obliquely against the atrial septum. All patients who received a mitral prosthesis larger than $25 \mathrm{~mm}$ in diameter were older than 6 years of age, except one who was only 3 years of age. In the Friedman, Edmunds, and Cuasco ${ }^{8}$ series, all three patients who underwent MVR when younger than 4 years of age required a second valve replacement 8.5 years later. This procedure will possibly apply to the 2-year-old patient who received a $19 \mathrm{~mm}$ prosthesis. Six of the nine patients who underwent AVR received a prosthesis larger than 21 $\mathrm{mm}$ in diameter, and only two required the insertion of a $19 \mathrm{~mm}$ prostheses. The satisfactory hemodynamic function of the implanted prostheses is clinically reflected in the fact that 16 of the 19 survivors were in NYHA functional class I and two patients were in class II. The only patient in class III had subpulmonary stenosis and was on 
the waiting list for correction at the time this article was written.

The present study illustrates excellent results of valve replacement in children with the St. Jude Medical prosthesis and the safety of warfarin anticoagulation therapy in this age group. We recommend the use of this prosthesis in children if valve repair is not feasible.

\section{REFERENCES}

1. Solymar L, Rao S, Mardini MK, Fawzy ME, Guinn G. Prosthetic valves in children and adolescents. Am Heart J 1991;121:557-68.

2. Zweng TN, Bluett MK, Mosca R, Callow LB, Bove EL. Mitral valve replacement in the first 5 years of life. Ann Thorac Surg 1989;47:720-4.

3. Fiddler GI, Gerlis LM, Walker DR, Scott O, Williams GJ. Calcification of glutaraldehyde-preserved porcine and povine xenograft valves in young children. Ann Thorac Surg 1983;35:257-61.

4. Miller DC, Stinson EB, Oyer PE, et al. The durability of porcine xenograft valves and conduits in children. Circulation 1982;66(Suppl):I172-85.

5. Milano A, Vouhe PR, Baillot-Vernant F, et al. Late results after left-sided cardiac valve replacement in children. J Thorac Cardiovasc Surg 1986;92:218-25.

6. Williams DB, Danielson GK, McGoon DC, Puga FJ, Mair DD, Edwards WD. Porcine heterograft valve replacement in children. J ThoraC CARdiovasC Surg 1982;84: 446-50.

7. Sanders SP, Levy RJ, Freed MD, Norwood WI, Castaneda AR. Use of Hancock porcine xenografts in children and adolescents. Am J Cardiol 1985;46:429-38.

8. Friedman S, Edmunds LH, Cuaso CC. Long-term mitral valve replacement in young children: influence of somatic growth on prosthetic valve adequacy. Circulation 1978; 57:981-6.

9. Williams WG, Pollock JC, Geiss DM, Trusler GA, Fowler RS. Experience with aortic and mitral valve replacement in children. J ThORAC CARDIOvaSC SURG 1981;81:326-33.

10. Ilbawi MN, Lockhart CG, Idriss FS, et al. Experience with St. Jude Medical valve prosthesis in children: a word of caution regarding right-sided placement. J THORAC CARDIOVASC SURG 1987;93:73-9.

11. Pass HI, Sade RM, Crawford FA, Hohn AR. Cardiac valve prostheses in children without anticoagulation. J THORAC Cardiovasc Surg 1984;87:832-5.

12. Sade RM, Crawford FA, Fyfe DA, Stroud MR. Valve prostheses in children: a reassessment of anticoagulation. $\mathrm{J}$ Thorac Cardiovasc Surg 1988;95:553-61.

13. Borkon AM, Soule L, Reitz BA, Gott VL, Gardner TJ. Five years follow-up after valve replacement with the St. Jude Medical valve in infants and children. Circulation 1986; 74(Suppl):I1 10-5.

14. El Makhlouf A, Friedli B, Oberhansli I, Rouge JC, Faidutti B. Prosthetic heart valve replacement in children: results and follow-up of 273 patients. J THORAC CARDIOVASC SURG 1987;93:80-5.

15. Verrier ED, Tranbaugh RF, Soifer SJ, Yee ES, Turley K, Ebert PA. Aspirin anticoagulation in children with mechanical aortic valves. J THORAC CARDIOvaSC SURG 1986;92:1013-20.

16. McGrath LB, Gonzalez-Lavin L, Eldredge WJ, Colombi M, Restrepo D. Thromboembolic and other events following valve replacement in a pediatric population treated with antiplatelet agents. Ann Thorac Surg 1987;43:285-7.

17. Rao PS, Solymar L, Mardini MK, Fawzy ME, Guinn G. Anticoagulant therapy in children with prosthetic valves. Ann Thorac Surg 1989;47:589-92.

18. Schaffer MS, Clarke DR, Campbell DN, Madigan CK, Wiggins JW, Wolfe RR. The St. Jude Medical cardiac valves in infants and children: role of anticoagulant therapy. J Am Coll Cardiol 1987;9:235-9.

19. Harada Y, Imai Y, Kurosawa H, Ishihara K, Kawada M, FukuchiS. Ten-year follow-up after valve replacement with the St. Jude Medical prosthesis in children. J THORAC Cardiovasc Surg 1990;100:175-80.

20. Schaff HV, Danielson GK, DiDonato RM, Puga FJ, Mair DD, McGoon DC. Late results after Starr-Edwards valve replacement in children. J THORAC CARDIOvasC SURG 1984;88:583-9.

21. Attie F, Lopez-Soriano F, Ovseyevitz J, et al. Late results of mitral valve replacement with the Bjork-Shiley prosthesis in children under 16 years of age. J THORAC CARDIOVASC SURG 1986;91:754-8.

22. Iyer KS, Reddy KS, Rao IM, Venugopal P, Bhatia ML, Gopinath N. Valve replacement in children under twenty years of age: experience with the Bjork-Shiley prosthesis. $J$ Thorac Cardiovasc SuRg 1984;88:217-24.

23. Guvendik L, Cobanoglu A, Davis NR, Fessler CL, Starr A. Valve replacement in children under 14 years of age: a review of 22 years of experience. Eur J Cardiothorac Surg 1989;3:229-34.

24. Gardner TJ, Roland JMA, Neil CA, Donaboo JS. Valve replacement in children: a fifteen year perspective. J THORAC CARdIOvaSC Surg 1982;83:178-85. 